\title{
A FRAGMENTAÇÃO DO DIREITO INTERNACIONAL: ENTRE O DISCURSO E A REALIDADE DO SISTEMA JURÍDICO INTERNACIONAL
}

\author{
FRAGMENTATION OF INTERNATIONAL LAW: BETWEEN THE DISCOURSE AND THE REALITY OF
}

INTERNATIONAL LEGAL SYSTEM

\section{Camilla Capucio*}

\begin{abstract}
Resumo:
O artigo objetiva analisar criticamente o discurso da fragmentação do Direito Internacional por meio de uma análise detalhada dos documentos da Comissão de Direito Internacional da ONU, verificando suas diferenças e inconsistências. A partir da crítica desta perspectiva que vislumbra na expansão do Direito Internacional motivos para o seu enfraquecimento, o trabalho destaca a visão sistêmica do Direito Internacional e sua relevância para o sistema jurídico contemporâneo. Embora a teoria da fragmentação seja base para diversos trabalhos acadêmicos na atualidade, faz-se relevante e necessário um exame detido sobre as diferentes nuances dos próprios documentos da Comissão que difundiram tal discurso, e por isso o trabalho se justifica. Adicionalmente, a atividade dos tribunais internacionais pode se dar de modo a harmonizar o sistema jurídico internacional e reforçar o papel do Direito Internacional como um instrumento universal.
\end{abstract}

Palavras-chave: Fragmentação. Direito Internacional. Sistema jurídico internacional. Comissão de Direito Internacional. Tribunais internacionais.

\begin{abstract}
:
This paper aims a detailed analysis of the documents of UN International Law Commission by checking differences and inconsistencies in order to review the discourse of fragmentation of International Law. From a critical point of view, that considers the expansion of International Law as the reason for its weakness, this paper highlights the systemic view of International Law and its relevance to the contemporary legal system. Whereas the fragmentation doctrine is the basis for many current academic papers, a close examination of the different nuances of the Commission's documents is relevant and needed for this paper. Additionally, the activity of international courts can harmonize the international legal system and to strengthen the role of international law as a universal tool.
\end{abstract}

Keywords: Fragmentation. International Law. International legal order. International Law Commission. International courts.

\footnotetext{
Doutora em Direito Internacional pela Faculdade de Direito da USP. Mestre e Graduada em Direito pela Faculdade de Direito da UFMG. Professora do Centro Universitário UNA. Professora convidada de cursos de pós-graduação latu sensu. Pesquisadora do Núcleo de Estudos em Tribunais Internacionais (NETIUSP). Pesquisadora do grupo de pesquisa Empresa, Mercado e Desenvolvimento Social (UNA). E-mail: ccapucio@usp.br; camillacapucio@gmail.com.
} 
1. Introdução

O Direito Internacional, desde sua origem como disciplina com objetivos e dimensões diversas dos ordenamentos jurídicos Estatais, enfrenta uma postura de ceticismo. Características próprias desta ordem normativa, como a ausência de força coercitiva central, a identidade entre os sujeitos criadores e aqueles destinatários das normas, e a relativa fluidez do exercício das diferentes funções na sociedade internacional são alguns dos argumentos com os quais os internacionalistas se depararam ao longo dos séculos, oferecidos pelos incrédulos no fenômeno jurídico internacional.

Entretanto, note-se que as transformações observadas nas últimas décadas e suas consequências tornaram a postura de negação da existência e juridicidade do Direito Internacional minoritária e insustentável. Determinados processos e eventos tais como a globalização/mundialização, a criação de Organizações Internacionais - principalmente da ONU, a internacionalização dos direitos humanos, a construção do sistema multilateral de comércio e a influência do Direito Internacional em todos os ramos do direito interno, são exemplos do escancaro do Direito Internacional e de sua presença em virtualmente todas as dimensões das sociedades.

Referidos eventos e processos tem demonstrado a força renovadora do Direito Internacional, em um crescente movimento de institucionalização, fortalecimento e expansão de sua normatividade, validade e efetividade. A evolução da sociedade internacional comporta, portanto, uma notável evolução da própria configuração deste Direito Internacional que recairá sob ela.

Mais recentemente, esses mesmos processos e eventos trouxeram fenômenos como a especialização e a jurisdicionalização do Direito Internacional. A amplitude de searas sujeitas à normatividade internacional e a criação de respectivos tribunais internacionais e outras instâncias adjudicatórias responsáveis pela concretização dos diferentes ramos do Direito Internacional demonstram, em nosso entender, a positivo recrudescimento do international rule of law na sociedade internacional.

Contudo, tais fenômenos suscitaram o surgimento de uma linha de argumentação que passou a discursar academicamente sobre a "fragmentação" do Direito Internacional, em questionamento sobre a unidade e a coerência do Direito Internacional e, portanto, de sua configuração como um sistema. O discurso da fragmentação do Direito Internacional, tão difundido e presente na academia internacional nos últimos anos, tem inerente em si a ideia de ruptura e enfraquecimento da ordem jurídica internacional, sendo, de certa maneira, uma "nova" postura cética com a qual se depara cientificamente o internacionalista.

Para que se construa, entretanto, um pensamento crítico sobre o tema, é necessário investigar as suas bases. Deste modo, o trabalho propõe uma análise objetiva 
e desmistificada dos estudos sob os auspícios da Comissão de Direito Internacional, que teriam fortalecido esta posição doutrinária, fazendo-se necessário o retorno ao início da temática naquele órgão, bem como uma apresentação cuidadosa dos documentos resultantes desses estudos, e de sua "titularidade".

\section{A análise da temática pela Comissão de Direito Internacional}

A Comissão de Direito Internacional - CDI (International Law ComissionILC) é órgão da ONU, criado em 1947, com o objetivo de "promoção do desenvolvimento progressivo do Direito Internacional e de sua codificação". ${ }^{1}$ Sua criação se deu como modo de implementar o comando do art. 13, parágrafo 1 da Carta da ONU, ${ }^{2}$ que atribuía esta função à Assembleia Geral. ${ }^{3}$ As atividades da Comissão estão a cargo de seus trinta e quatro membros, pessoas de reconhecida competência em Direito Internacional, eleitos a título individual, e não como representantes de posicionamento de seus respectivos Estados. ${ }^{4}$

Em sua 52a sessão, em 2000, a CDI decidiu incluir em seu programa de trabalho de longo prazo o tópico de estudo "Risks ensuing from Fragmentation of International Law", a partir de estudo preliminar de Gerhard Hafner. ${ }^{5}$ Neste estudo, o autor

1 Estatuto da Comissão de Direito Internacional, adotado pela Assembleia Geral da ONU por meio da Resolução n. 174 (II) de 21 de novembro de 1947, emendada pelas Resoluções ns. 485 (V) de 12 de dezembro de 1950, 984 (X) de 3 de dezembro de 1955, 985 (X) de 3 de dezembro de 1955 e $36 / 39$ de 18 de novembro de 1981. Art. 1, Parágrafo 1: "1. The International Law Commission shall have for its object the promotion of the progressive development of international law and its codification."

2 “Art. 13. 1. AAssembleia Geral iniciará estudos e fará recomendações, destinados a: a) promover cooperação internacional no terreno político e incentivar o desenvolvimento progressivo do direito internacional e a sua codificação; (...)"

3 Em sua primeira sessão, por meio da Resolução n. 94 (I), a Assembleia Geral criou o "Committee on the Progressive Development of International Law and its Codification”, também denominado informalmente de "Committee of Seventeen". Esse Comitê, que tinha como função estudar modos de implementar o comando do Art. 13, parágrafo 1 da Carta, ao final de suas atividades recomendou o estabelecimento da Comissão de Direito Internacional, e suas recomendações foram as bases para o desenho do Estatuto da CDI. Para mais detalhes sobre o histórico de sua criação, consulte o site oficial da ILC. Disponível em: $<$ http://untreaty.un.org/ilc/ilcintro.htm>.

4 Estatuto da Comissão de Direito Internacional, adotado pela Assembleia Geral da ONU por meio da Resolução n. 174 (II) de 21 de novembro de 1947, emendada pelas Resoluções ns. 485 (V) de 12 de dezembro de 1950, 984 (X) de 3 de dezembro de 1955, 985 (X) de 3 de dezembro de 1955 e $36 / 39$ de 18 de novembro de 1981. Art. 2: "1. The Commission shall consist of thirty-four members who shall be persons of recognized competence in international law. 2. No two members of the Commission shall be nationals of the same State. 3. In case of dual nationality a candidate shall be deemed to be a national of the State in which he ordinarily exercises civil and political rights." Conjugado com o Art. 8: "At the election the electors shall bear in mind that the persons to be elected to the Commission should individually possess the qualifications required and that in the Commission as a whole representation of the main forms of civilization and of the principal legal systems of the world should be assured."

5 G. Hafner, "Risks Ensuing from Fragmentation of International Law", Official Records of the General Assembly, Fifty-fifth session, Supplement No. 10 (A/55/10), annex. United Nations. International Law 
afirma que recentemente, em particular desde o fim da guerra fria, o Direito Internacional teria sido objeto de uma maior fragmentação- embora sem definir exatamente este conceito- e liga a este fenômeno a afirmação de que não há um sistema homogêneo de Direito Internacional na atualidade. ${ }^{6}$

Embora reconhecendo que essa natureza do Direito Internacional, enquanto resultado de "subsistemas jurídicos separados e erráticos", tem um efeito positivo ao reforçar o império do Direito nas relações internacionais, haveria o risco de fricções e contradições entre regulações diferentes, podendo ensejar em responsabilidade internacional dos Estados. ${ }^{7}$

Como causas da fragmentação, o autor apontava: (i) a falta de órgãos centralizados, ${ }^{8}$ (ii) a especialização temática, ${ }^{9}$ (iii) a formação do Direito Internacional

Commission. Report on the work of its fifty-second session (1 May-9 June and 10 July-18 August 2000). General Assembly Official Records, Fifty-fifth Session. Supplement No. 10 (A/55/10). p. 143-150. Disponível em: $<$ http://untreaty.un.org/ilc//reports/2000/english/annex.pdf $>$.

6 UNITED NATIONS. International Law Commission. Report on the work of its fifty-second session (1 May9 June and 10 July-18 August 2000). General Assembly Official Records, Fifty-fifth Session. Supplement No. 10 (A/55/10). Disponível em: <http://untreaty.un.org/ilc//reports/2000/english/annex.pdf>. "It can therefore easily be assumed that, presently, there exists no homogeneous system of international law. As it has been noted at several occasions, even during recent discussions in the Commission, inter alia, on State responsibility, existing international law does not consist of (p. 143) one homogenous legal order, but mostly of different partial systems, producing an "unorganized system". Hence, the system of international law consists of erratic parts and elements which are differently structured so that one can hardly speak of a homogeneous nature of international law. This system is full of universal, regional or even bilateral systems, subsystems and subsubsystems of different levels of legal integration". p. 143-145.

7 UNITED NATIONS. International Law Commission. Report on the work of its fifty-second session (1 May9 June and 10 July-18 August 2000). General Assembly Official Records, Fifty-fifth Session. Supplement No. 10 (A/55/10). Disponível em: <http://untreaty.un.org/ilc//reports/2000/english/annex.pdf \$. "This nature of international law resulting from separate erratic legal subsystems undoubtedly has a positive effect insofar as it enforces the rule of law in international relations; nevertheless, it is exposed to the risk of generating frictions and contradictions between the various legal regulations and creates the risk that States even have to comply with mutually exclusive obligations. Since they cannot respect all such obligations, they inevitably incur State responsibility". p. 144.

8 UNITED NATIONS. International Law Commission. Report on the work of its fifty-second session (1 May-9 June and 10 July-18 August 2000). General Assembly Official Records, Fifty-fifth Session. Supplement No. 10 (A/55/10). Disponível em: <http://untreaty.un.org/ilc//reports/2000/english/annex.pdf>. "Fragmentation stems from the nature of international law as a law of coordination instead of subordination as well as from the lack of centralized institutions which would ensure homogeneity and conformity of legal regulations." p. 145.

9 UNITED NATIONS. International Law Commission. Report on the work of its fifty-second session (1 May-9 June and 10 July-18 August 2000). General Assembly Official Records, Fifty-fifth Session. Supplement No. 10 (A/55/10). Disponível em: <http://untreaty.un.org/ilc//reports/2000/english/annex. pdf>. "This development leads to "topic autonomy" with strange results (environmentalists neglecting State responsibility, human rights advocates being unaware of the rules concerning the treatment of aliens, etc.). Accordingly, two principal threats to the unity of international law surface: the type of irregular specialization and political divisions on particular issues (in particular according to the North/South conflict)." p. 145. 
por meio de diferentes estruturas normativas, ${ }^{10}$ (iv) as regulações paralelas ${ }^{11}$ ou (v) competitivas entre os "regimes", ${ }^{12}$ (vi) a expansão do escopo do Direito Internacional, ${ }^{13}$ (vii) e a existência de diferentes "regimes de regras secundárias" (Tribunais Internacionais). ${ }^{14}$ Ainda seguindo o tom alarmante deste relato, a "desintegração" da ordem jurídica internacional conduziria à ameaça da confiabilidade, credibilidade e autoridade do Direito Internacional, vez que, em sua perspectiva, poderia haver dúvidas quanto à capacidade do Direito Internacional de adimplir com sua função primária de pacificação e estabilização das relações internacionais. ${ }^{15}$

10 Existing international law faces at least three different legal structures: (1) classical international law consisting mainly of reciprocal norms of synallagmatic nature, i.e. norms creating bilateral reciprocal relations among States which leads to a splitting of the universal legal order in bilateral legal relations; (2) new developments of international law imposing duties on States owed to individuals such as norms protecting human rights; or (3) duties owed to the community of States as such participating in a given legal system. p. 146.

11 UNITED NATIONS. International Law Commission. Report on the work of its fifty-second session (1 May9 June and 10 July-18 August 2000). General Assembly Official Records, Fifty-fifth Session. Supplement No. 10 (A/55/10). Disponível em: <http://untreaty.un.org/ilc//reports/2000/english/annex.pdf>. "A further threat to the unity of international law stems from the parallel regulation on the universal or the regional level relating to the same matter. (...)Solutions to the question of which of them is applicable in a given case are mostly found by a reference to the provisions in these treaties attaching priority to the more specific conventions and to the lex specialis rule. Nevertheless, even these legal devices cannot always solve issues, in particular if non-riparian States are involved." p. 146.

12 UNITED NATIONS. International Law Commission. Report on the work of its fifty-second session (1 May9 June and 10 July-18 August 2000). General Assembly Official Records, Fifty-fifth Session. Supplement No. 10 (A/55/10). Disponível em: <http://untreaty.un.org/ilc//reports/2000/english/annex.pdf>. "Generally, this situation could also be engendered by the elaboration of different legal regimes in different international negotiation bodies, both addressing the same group of States." p. 146.

13 UNITED NATIONS. International Law Commission. Report on the work of its fifty-second session (1 May9 June and 10 July-18 August 2000). General Assembly Official Records, Fifty-fifth Session. Supplement No. 10 (A/55/10). Disponível em: <http://untreaty.un.org/ilc//reports/2000/english/annex.pdf>. "On a more general level, this fragmented nature of international law, according to Dupuy, is due to the enlargement of the material scope of international law, a multiplication of actors, and an effort to improve the efficiency of public international obligations, with the establishment of some conventional and sophisticated "follow- u" machinery, in particular in the fields of human rights, international economic law, international trade law, and international environmental law". p. 146-147.

14 UNITED NATIONS. International Law Commission. Report on the work of its fifty-second session (1 May9 June and 10 July-18 August 2000). General Assembly Official Records, Fifty-fifth Session. Supplement No. 10 (A/55/10). Disponível em: <http://untreaty.un.org/ilc//reports/2000/english/annex.pdf>. "In order to avoid possible conflicts ensuing there from, the States chose to equip the primary norms with special secondary norms which would have precedence over the general secondary norms of international law. These special secondary norms should ensure that the primary norms were respected, properly administered and violations of the norms adequately met. International courts have also addressed the issue, focusing generally on the question of precedence of the secondary norms of such mechanisms or subsystems over the general secondary norms of international law". p. 146.

15 UNITED NATIONS. International Law Commission. Report on the work of its fifty-second session (1 May9 June and 10 July-18 August 2000). General Assembly Official Records, Fifty-fifth Session. Supplement No. 10 (A/55/10). Disponível em: <http://untreaty.un.org/ilc//reports/2000/english/annex.pdf>. p. 146-147. 
Não podendo ignorar o caráter "atípico" do tópico a ser apreciado pela Comissão, o relator expõe que existiam duas exceções à prática de produção de draft articles ao final das discussões, sugerindo que a Comissão poderia produzir como resultado de suas discussões um relatório que identificasse os supostos problemas resultantes dessa temática, ou uma "compilação de materiais", que chamasse a atenção dos Estados para a grande diversidade de regulações jurídicas existentes e para os possíveis riscos resultantes desse problema. ${ }^{16}$

Assim, embora sem oferecer ao menos um primeiro conceito acerca da fragmentação, em um tom exacerbadamente alarmante, a justificativa apresentada para a inclusão deste tópico no trabalho da Comissão seria, segundo este relato, os riscos que a fragmentação causaria à estabilização do Direito Internacional e à sua consistência. ${ }^{17}$

Em sua 54ª sessão, em 2002, a Comissão decidiu incluir o tópico em seu cronograma de trabalho, instituindo naquela data um grupo de estudo sob o comando do seu então membro Bruno Simma, e modificando o título do tópico para "Fragmentation of international law: difficulties arising from the diversification and expansion of international law". ${ }^{18}$

O breve sumário das discussões do grupo de estudos anexado ao relatório da CDI daquele ano, exatamente por ter sido objeto de prévia discussão intersubjetiva, apresenta um tom consideravelmente mais brando e moderado, face ao alarmismo presente no estudo preliminar de Gerhard Hafner.

O texto destaca que a Comissão reconhece que este tópico tem a natureza diferente de todos os outros, mas que sua natureza única não obstaria o seu estudo pela CDI. Houve também, naquela oportunidade, um acordo entre os membros de que fragmentação não era um novo fenômeno, vez que o Direito Internacional é inerentemente "um direito de um mundo fragmentado", e tratá-lo como um novo fenômeno poderia causar distração

16 UNITED NATIONS. International Law Commission. Report on the work of its fifty-second session (1 May9 June and 10 July-18 August 2000). General Assembly Official Records, Fifty-fifth Session. Supplement No. 10 (A/55/10). Disponível em: <http://untreaty.un.org/ilc//reports/2000/english/annex.pdf>. p. 149-150.

17 UNITED NATIONS. International Law Commission. Report on the work of its fifty-second session (1 May-9 June and 10 July-18 August 2000). General Assembly Official Records, Fifty-fifth Session. Supplement No. 10 (A/55/10). Disponível em: <http://untreaty.un.org/ilc//reports/2000/english/annex.pdf>. "The primordial task of the Commission is the codification and progressive development of international law (Article 13 of the Charter of the United Nations) in the interest of the stabilization of international law and, consequently, international relations. Since the fragmentation of international law could endanger such stability as well as the consistency of international law and its comprehensive nature, it would fall within the purview of the objectives to be attained by the Commission to address these problems. Hence, the Commission should seek ways and means to overcome the possible detrimental effects of such fragmentation". p. 144.

18 UNITED NATIONS. International Law Commission. Report on the work of its fifty-fourth session (29 April - 7 June and 22 July - 16 August 2002) General Assembly Official Records, Fifty-seventh Session. Supplement No. 10 (A/57/10). Disponível em: <http://untreaty.un.org/ilc//reports/2002/2002report.htm>. Parágrafo 496. 
quanto aos mecanismos existentes que o Direito Internacional teria desenvolvido ao longo do tempo para lidar com "os desafios resultantes da fragmentação”.

Destaque deve ser dado para a mudança do título, de "riscos" para "dificuldades", evidenciando que desde o início dos estudos a visão negativa do fenômeno não era prevalecente ou única entre os membros da Comissão, que explicitamente afirmaram a inadequação do primeiro título "because it depicted the phenomena described by the term "fragmentation" in too negative a light". ${ }^{19}$

Assim, em desconformidade com a percepção inicial de alarme e desconstrução, nota-se o contraponto de parte dos membros da CDI, que partem de outra visão do Direito Internacional e do fenômeno então em discussão:

The work of the Commission would have to be guided by the aim of countering such risks and challenges. On the other hand, the Study Group also thought it important to highlight the positive aspects of fragmentation. For example, fragmentation could be seen as a sign of the vitality of international law. It was also suggested that the proliferation of rules, regimes and institutions might strengthen international law. The same was true of regional international law and institutions. Attention was drawn to the fact that the increasing scope of international law meant that areas that were previously unaddressed by international law were being addressed. Similarly, there were advantages in increased diversity of voices and a polycentric system in international law. ${ }^{20}$

Isso denota que há, desde o início, uma tensão dialética entre visões diferentes do Direito Internacional, dos tribunais internacionais e de sua função na sociedade internacional.

A partir da $55^{\mathrm{a}}$ sessão, em 2003, com a eleição do então chairman Bruno Simma para o cargo de juiz da Corte Internacional de Justiça, o grupo de trabalho para o tópico passou a ser guiado por Martti Koskenniemi. ${ }^{21}$ Naquele ano a temática foi melhor

19 UNITED NATIONS. International Law Commission. Report on the work of its fifty-fourth session (29 April - 7 June and 22 July - 16 August 2002) General Assembly Official Records, Fifty-seventh Session. Supplement No. 10 (A/57/10). Disponível em: <http://untreaty.un.org/ilc//reports/2002/2002report.htm>. Parágrafo 497; 500.

20 UNITED NATIONS. International Law Commission. Report on the work of its fifty-fourth session (29 April - 7 June and 22 July - 16 August 2002) General Assembly Official Records, Fifty-seventh Session. Supplement No. 10 (A/57/10). Disponível em: <http://untreaty.un.org/ilc//reports/2002/2002report.htm>. Parágrafo 498.

21 UNITED NATIONS. International Law Commission. Report on the work of its fifty-fifth session (5 May to 6 June and 7 July to 8 August 2003) General Assembly Official Records, Fifty-eighth Session. Supplement No. 10 (A/58/10). Disponível em: <http://untreaty.un.org/ilc//reports/2003/english/chp10.pdf>. Parágrafo 412 . 
delimitada, seguindo as recomendações da Comissão expressas no relatório do grupo de trabalho do ano anterior e o sumário das discussões do Sexto Comitê da Assembleia Geral em sua $57^{\mathrm{a}}$ sessão. ${ }^{22}$ Foi também traçado um cronograma para a realização e conclusão dos trabalhos, e feita a distribuição da função de preparação de esboços entre os seguintes membros do grupo de trabalho, além de seu chairman: ${ }^{23}$ William Mansfield; ${ }^{24}$ Teodor Melescanu; ${ }^{25}$ Riad Daoudi; ${ }^{26}$ e Zdzislaw Galicki. ${ }^{27}$

$\mathrm{Na} 56^{\mathrm{a}}$ sessão, em $2004,{ }^{28}$ foram apresentados os esboços iniciais dos respectivos responsáveis e feitas considerações por parte dos demais membros da CDI. No que interessa ao desenvolvimento deste trabalho, merecem destaque alguns trechos do Relatório da Comissão que sumariza as discussões.

O relatório explicita que, embora algumas de suas concepções tenham gerado críticas de outros membros ${ }^{29}$ o chairman Martti Koskenniemi observa que a

22 Documento preparado pelo Secretariado, A/CN.4/529, sect. F.

23 Naquela fase inicial, era o responsável pelo desenvolvimento do esboço do item "The function and scope of the lex specialis rule and the question of "self-contained regimes". Um esboço inicial já havia sido apresentado à CDI pelo relator naquele ano, e foi desenvolvido e discutido nos anos seguintes: ILC(LVI)/ SG/FIL/CRD.1 e Add.1. Disponível em: <http://untreaty.un.org/ilc//sessions/55/fragmentation_outline. $\mathrm{pdf}>$.

24 UNITED NATIONS. International Law Commission. Report on the work of its fifty-fifth session (5 May to 6 June and 7 July to 8 August 2003) General Assembly Official Records, Fifty-eighth Session. Supplement No. 10 (A/58/10). Disponível em: <http://untreaty.un.org/ilc//reports/2003/english/chp10.pdf>. Parágrafo 427 (a). Responsável pelo item "The interpretation of treaties in the light of "any relevant rules of international law applicable in the relations between the parties" (article 31 (3) (c) of the Vienna Convention on the Law of Treaties), in the context of general developments in international law and concerns of the international community".

25 UNITED NATIONS. International Law Commission. Report on the work of its fifty-fifth session (5 May to 6 June and 7 July to 8 August 2003) General Assembly Official Records, Fifty-eighth Session. Supplement No. 10 (A/58/10). Disponível em: <http://untreaty.un.org/ilc//reports/2003/english/chp10.pdf>. Parágrafo 427 (b). Responsável pelo item “(b) The application of successive treaties relating to the same subject matter (article 30 of the Vienna Convention on the Law of Treaties)".

26 UNITED NATIONS. International Law Commission. Report on the work of its fifty-fifth session (5 May to 6 June and 7 July to 8 August 2003) General Assembly Official Records, Fifty-eighth Session. Supplement No. 10 (A/58/10). Disponível em: < http://untreaty.un.org/ilc//reports/2003/english/chp10.pdf>. Parágrafo 427 (c). Responsável pelo item "The modification of multilateral treaties between certain of the parties only (article 41 of the Vienna Convention on the Law of Treaties)".

27 UNITED NATIONS. International Law Commission. Report on the work of its fifty-fifth session (5 May to 6 June and 7 July to 8 August 2003) General Assembly Official Records, Fifty-eighth Session.Supplement No. 10 (A/58/10). Disponível em: <http://untreaty.un.org/ilc//reports/2003/english/chp10.pdf>. Parágrafo 427 (d). Responsável pelo item "Hierarchy in international law: jus cogens, obligations erga omnes, Article 103 of the Charter of the United Nations, as conflict rules".

28 UNITED NATIONS. International Law Commission. Report on the work of its fifty-sixth session (3 May to 4 June and 5 July to 6 August 2004) General Assembly Official Records, Fifty-ninth Session. Supplement No. 10 (A/59/10). Disponível em: <http://untreaty.un.org/ilc//reports/2004/2004report.htm>.

29 UNITED NATIONS. International Law Commission. Report on the work of its fifty-sixth session (3 May to 4 June and 5 July to 6 August 2004) General Assembly Official Records, Fifty-ninth Session. Supplement No. 10 (A/59/10). Disponível em: <http://untreaty.un.org/ilc//reports/2004/2004report.htm>. Parágrafo 313. "Some members of the Study Group doubted the suggestion that the lex specialis maxim denoted 
orientação geral de seu estudo é destacar a relevância continuada do Direito Internacional geral em relação aos "regimes auto-contidos". ${ }^{30}$

No que tange este último conceito, expressou-se a conclusão de que sua própria denominação era inoportuna, vez que inexistem na realidade grupos de regras isolados do Direito Internacional Geral. ${ }^{31}$ Este isolamento não seria nem mesmo possível, uma vez que estes grupos de regras buscam sua própria validade do Direito Internacional Geral.

\section{É de máxima relevância a afirmação do chairman de que a principal} conclusão de seu estudo, naquele dado momento, seria:

that the present use of the lex specialis maxim or the emergence of special treaty-regimes had not seriously undermined legal security, predictability or the equality of legal subjects. These techniques gave expression to concerns about economic development, protection of human rights and the environment, and regionalism that were both legitimate and strongly felt. The system was not in a crisis. ${ }^{32}$

an informal hierarchy. In their view, there was no hierarchy, formal or informal, between the sources of international law. If a treaty was normally given priority to a general custom this was not due to a hierarchy in law but merely to the need to give effect to the will of the parties - it was not inconceivable that a special custom might have priority over a general treaty for that same reason. In any case, there was reason to distinguish between priority between legal sources and priority between legal norms. There was also some criticism of the Chairman's treatment of the question of the ability to derogate from general law. Aside from the issue of jus cogens, the question of permissibility to derogate remained still an unclear matter".

30 UNITED NATIONS. International Law Commission. Report on the work of its fifty-sixth session (3 May to 4 June and 5 July to 6 August 2004) General Assembly Official Records, Fifty-ninth Session. Supplement No. 10 (A/59/10). Disponível em: <http://untreaty.un.org/ilc//reports/2004/2004report.htm>. "314. In introducing the part of his study concerning self-contained regimes (Addendum 1), the Chairman observed that the general thrust of his study was to accentuate the continued importance of general law. This was natural, he stated, as the rationale for the two was the same. Self-contained regimes were a subcategory of lex specialis".

31 UNITED NATIONS. International Law Commission. Report on the work of its fifty-sixth session (3 May to 4 June and 5 July to 6 August 2004) General Assembly Official Records, Fifty-ninth Session. Supplement No. 10 (A/59/10). Disponível em: <http://untreaty.un.org/ilc//reports/2004/2004report.htm>. "para 317. The main conclusion from the Commission's earlier debates was that neither the Commission nor the Special Rapporteurs - nor any of the cases regularly discussed in this connection - implied that the special rules would be fully isolated from general international law. 318. The Chairman suggested that in fact the term "self-contained regime" was a misnomer in the sense that no set of rules - whether in the narrower or the broader sense - was isolated from general law. He doubted whether such isolation was even possible: a regime can receive (or fail to receive) legally binding force ("validity") only by reference to (valid and binding) rules or principles outside it." Para 321. (...) Chairman observed that in none of the existing treatyregimes was the application of general international law excluded. On the contrary, the treaty bodies made constant use of general international law.

32 UNITED NATIONS. International Law Commission. Report on the work of its fifty-sixth session (3 May to 4 June and 5 July to 6 August 2004) General Assembly Official Records, Fifty-ninth Session. Supplement No. 10 (A/59/10). Disponível em: <http://untreaty.un.org/ilc//reports/2004/2004report.htm>. Parágrafo 323. 
$\mathrm{Na} 57^{\mathrm{a}}$ sessão, em 2005, ${ }^{33}$ as discussões se concentraram nos esboços parciais dos demais temas do tópico, uma vez já realizada discussão aprofundada sobre o tema da lex specialis e os "regimes auto-contidos" na sessão anterior. Este primeiro tema, contudo, foi complementado com a discussão do regionalismo, que também suscitou visões diversas. $^{34}$

No esboço apresentado por William Mansfield em relação ao art. 31 (3) (c) da Convenção de Viena de Direito dos Tratados, há o reconhecimento da existência de um princípio de integração sistêmica, como um guia de interpretação que localiza o tratado no Direito Internacional compreendido como um sistema, ${ }^{35}$ bem como da relevância dos princípios gerais do direito e regras costumeiras em sua "função constitucional" de integração sistêmica na hermenêutica das regras convencionais. ${ }^{36}$

Contudo, em mais um embate de diferentes concepções, o grupo de estudo afirmou levar em consideração os apontamentos deste esboço, mas preferia adotar a noção

33 UNITED NATIONS. International Law Commission. Report on the work of its fifty-seventh session (2 May to 3 June and 11 July to 5 August 2005). General Assembly Official Records, Sixtieth Session Supplement No. 10 (A/60/10). Disponível em: <http://untreaty.un.org/ilc//reports/2005/english/chp11.pdf> .

34 UNITED NATIONS. International Law Commission. Report on the work of its fifty-seventh session (2 May to 3 June and 11 July to 5 August 2005). General Assembly Official Records, Sixtieth Session Supplement No. 10 (A/60/10). Disponível em: < http://untreaty.un.org/ile//reports/2005/english/chp11.pdf>. Parágrafo 466. "On the basis of the discussion, the Study Group agreed that "regionalism" should not have a separate entry in the final substantive report. Rather, various aspects of the memorandum and the debate would be used as examples in the overall schema of the topic, especially in connection with the lex specialis rule. Mention of regionalism as a factor contributing to fragmentation should also be included in the introduction of the final report. It should be borne in mind, however, that its role was not only negative. (...)"

35 UNITED NATIONS. International Law Commission. Report on the work of its fifty-seventh session (2 May to 3 June and 11 July to 5 August 2005). General Assembly Official Records, Sixtieth Session Supplement No. 10 (A/60/10). Disponível em: <http://untreaty.un.org/ilc//reports/2005/english/chp11.pdf >. Parágrafo 467 It expressed what could be called a principle of "systemic integration", that is to say, a guideline according to which treaties should be interpreted against the background of all the rules and principles of international law - in other words, international law understood as a system. The negotiation of individual treaties usually took place as separate diplomatic and practical exercises, conducted by experts in the particular field of regulatory substance covered by the treaty. It was the objective of article 31 (3) (c) to connect the separate treaty provisions that followed from such exercises to each other as aspects of an overall aggregate of the rights and obligations of States. As an interpretative tool, the principle expresses the nature of a treaty as an agreement "governed by international law".

36 UNITED NATIONS. International Law Commission. Report on the work of its fifty-seventh session (2 May to 3 June and 11 July to 5 August 2005). General Assembly Official Records, Sixtieth Session Supplement No. 10 (A/60/10). Disponível em: <http://untreaty.un.org/ilc//reports/2005/english/chp11.pdf>. Parágrafo 471. "The importance of custom and general principles is highlighted whenever a treaty provision is unclear or open-textured or when the terms used in the treaty have a recognized meaning in customary international law, to which the parties can therefore be taken to have intended to refer.386 The process may on occasion involve extensive investigation of sources outside the treaty in order to determine the content of the applicable rule of custom or general principle (as in Al-Adsani and Oil Platforms). The significance of rules of customary international law and general principles of law in this process is in the fact that they perform a systemic or constitutional function in describing the operation of the international legal order". 
de "objetivo" de integração sistêmica, ao invés de "princípio", questionando a existência de embasamento desse princípio no texto da Convenção. ${ }^{37}$

Em relação à temática da hierarquia no Direito Internacional, foi também debatido o princípio da harmonização. Embora o princípio fosse reconhecido no esboço elaborado por Zdzislaw Galicki, ${ }^{38}$ estudo tido como mais abstrato e acadêmico, alguns membros do grupo de trabalho buscaram desqualificar o papel deste princípio e a hierarquia como um raciocínio analiticamente útil ao Direito Internacional. ${ }^{39}$

37 UNITED NATIONS. International Law Commission. Report on the work of its fifty-seventh session (2 May to 3 June and 11 July to 5 August 2005). General Assembly Official Records, Sixtieth Session Supplement No. 10 (A/60/10). Disponível em: <http://untreaty.un.org/ilc//reports/2005/english/chp11.pdf>. "Parágrafo 475. The Study Group welcomed the revised paper by Mr. Mansfield, endorsing in general terms the adoption of an interpretative approach to article 31 (3) (c) that may be of practical use to judges and administrators. The approach taken to achieve systemic integration was felt to be consistent with the approach taken by the Group in its discussion of the Chairman's report on the lex specialis and the question of "self-contained regimes" the previous year.395 Some members still felt that there was, perhaps, a need for a grounding of such a principle in the Vienna Convention itself. Accordingly, the Study Group preferred to refer, instead of "principle", to the "objective" of systemic integration. According to this objective, whatever their subject matter, treaties are a creation of the international legal system and their operation is predicated upon that fact".

38 UNITED NATIONS. International Law Commission. Report on the work of its fifty-seventh session (2 May to 3 June and 11 July to 5 August 2005). General Assembly Official Records, Sixtieth Session Supplement No. 10 (A/60/10). Disponível em: <http://untreaty.un.org/ilc//reports/2005/english/chp11.pdf>. "484. The report further highlighted the close connection between the study on hierarchy in international law and the other four studies. The conclusions by the Study Group on this study would thus depend on the conclusions emerging from the other studies, and the former would in return have consequences for the results of the latter. In this connection, it was suggested that conclusions could be further developed around a number of clusters concerning (a) the general concept of hierarchy in international law; (b) the acceptance and rationale of hierarchy in international law; (c) the relationship between the various norms under consideration; and (d) the relationship between hierarchy and fragmentation of international law. As regards the relationship between the various norms under consideration, the paper by Mr. Galicki suggested the necessity to recognize the principle of harmonization."

39 UNITED NATIONS. International Law Commission. Report on the work of its fifty-seventh session (2 May to 3 June and 11 July to 5 August 2005). General Assembly Official Records, Sixtieth Session Supplement No. 10 (A/60/10). Disponível em: <http://untreaty.un.org/ilc//reports/2005/english/chp11.pdf>. 487. While there was no hierarchy as such between sources of international law, general international law recognized that certain norms have a peremptory character. Certain rules were recognized as superior or having a special or privileged status because of their content, effect, scope of application, or on the basis of consent among parties. The rationale of hierarchy in international law found its basis in the principle of the international public order, and its acceptance is reflected in examples of such norms of jus cogens, obligations erga omnes, as well as treaty-based provisions such as Article 103 of the Charter.397 The notion of public order is a recognition of the fact that some norms are more important or less important than others. Certain rules exist to satisfy the interests of the international community as a whole. Some members of the Study Group, however, felt that the metaphor of hierarchy in international law was not analytically helpful, and that it needed to be contextualized within specific relationships between norms of international law. It was stressed that hierarchy operated in a relational and contextual manner. 493. Some members of the Study Group doubted that the principle of harmonization had a particular role to play in the relationship between norms of jus cogens and other norms. The Study Group nevertheless recognized that the principle of harmonization should be seen as a cross-cutting interpretive principle, applicable also in hierarchical relations to the extent possible. 
Por fim, na $58^{\mathrm{a}}$ sessão, em 2006, ${ }^{40}$ foram apresentados como resultados oficiais dos estudos realizados pelo grupo dois documentos: (a) o relatório final do grupo de trabalho contendo as suas conclusões, e (b) um estudo analítico sobre o tema da fragmentação. É preciso diferenciar brevemente o conteúdo, status e autoria desses dois documentos, que por diversas vezes são confundidos, para que a análise das visões neles expressadas seja mais precisa.

O relatório final do grupo de trabalho é um "documento único de autoria coletiva, expressando as conclusões emergentes dos estudos e discussões no âmbito do grupo de trabalho". ${ }^{41} \mathrm{O}$ relatório, ${ }^{42}$ composto de quarenta e duas conclusões, tem um viés mais prático, e objetiva servir como guia concreto para a prática jurídica. Em sua sessão introdutória, o documento explicita que as conclusões são um "produto coletivo dos membros do Grupo de Estudos"43 e os nomina. ${ }^{44}$ A Comissão decidiu "tomar conhecimento" 45 do relatório, reproduzindo as conclusões do grupo de Trabalho em seu relatório anual (da CDI), e enviou à atenção da Assembleia Geral. ${ }^{46}$

40 UNITED NATIONS. International Law Commission. Report on the work of its fifty-eighth session (1 May to 9 June and 3 July to 11 August 2006). General Assembly Official Records, Sixty-first Session Supplement No. 10 (A/61/10). Disponível em: <http://untreaty.un.org/ilc//reports/2006/english/chp12.pdf>.

${ }^{41}$ UNITED NATIONS. International Law Commission. Report on the work of its fifty-eighth session (1 May to 9 June and 3 July to 11 August 2006). General Assembly Official Records, Sixty-first Session Supplement No. 10 (A/61/10). Disponível em: <http://untreaty.un.org/ilc//reports/2006/english/chp12.pdf>. Parágrafo 235 .

42 A/CN.4/L.702. United Nations, International Law Commission, General Assembly. 18 July 2006. Fiftyeighth session, Geneva, 1 May-9 June and 3 July-11 August 2006. "Fragmentation of International Law: Difficulties arising from the diversification and expansion of International Law. Report of the Study Group of the International Law Commission. Disponível em: <http://daccess-dds-ny.un.org/doc/UNDOC/LTD/ G06/628/63/PDF/G0662863.pdf?OpenElement>.

43 A/CN.4/L.702. United Nations, International Law Commission, General Assembly. 18 July 2006. Fiftyeighth session, Geneva, 1 May-9 June and 3 July-11 August 2006. "Fragmentation of International Law: Difficulties arising from the diversification and expansion of International Law. Report of the Study Group of the International Law Commission. Disponível em: <http://daccess-dds-ny.un.org/doc/UNDOC/LTD/ G06/628/63/PDF/G0662863.pdf?OpenElement>. Parágrafo 3.

44 A/CN.4/L.702. United Nations, International Law Commission, General Assembly. 18 July 2006. Fiftyeighth session, Geneva, 1 May-9 June and 3 July-11 August 2006. "Fragmentation of International Law: Difficulties arising from the diversification and expansion of International Law. Report of the Study Group of the International Law Commission. Disponível em: <http://daccess-dds-ny.un.org/doc/UNDOC/LTD/ G06/628/63/PDF/G0662863.pdf?OpenElement>. Nota de rodapé 4: "The following members participated in the work of the Study Group during the 2006 session: Mr. M. Koskenniemi (Chair), Mr. A. Al-Marri, Mr. C. Chee, Mr. P. Comissario Afonso, Mr. R. Daoudi, Mr. C.P. Economides, Ms. P. Escarameia, Mr. G. Gaja, Mr. Z. Galicki, Mr. R.A. Kolodkin, Mr. W. Mansfield, Mr. M. Matheson, Mr. P.S. Rao, Ms. H. Xue”.

45 UNITED NATIONS. International Law Commission. Report on the work of its fifty-eighth session (1 May to 9 June and 3 July to 11 August 2006). General Assembly Official Records, Sixty-first Session Supplement No. 10 (A/61/10). Disponível em: <http://untreaty.un.org/ilc//reports/2006/english/chp12.pdf >. Parágrafo 239. 2902nd meeting, 28 de julho.

46 UNITED NATIONS. International Law Commission. Report on the work of its fifty-eighth session (1 May to 9 June and 3 July to 11 August 2006). General Assembly Official Records, Sixty-first Session Supplement No. 10 (A/61/10). Disponível em: <http://untreaty.un.org/ilc//reports/2006/english/chp12.pdf>. Parágrafo. 
O estudo analítico sobre a questão da fragmentação, ${ }^{47}$ por sua vez, é documento extenso, "formulado a partir dos esboços individuais e estudos submetidos por membros individuais do Grupo de Estudos e discutidos no grupo"48 e finalizado pelo seu chairman, Martti Koskenniemi. Em sua página inicial, o chairman se intitula como "único responsável” pelo conteúdo do relatório e de qualquer opinião nele contida, embora mencionando o auxílio de diversos colegas em questões particulares. ${ }^{49}$ Em relação a este documento, a Comissão requereu "apenas" que fosse tornado público em seu website e em seu anuário, como é a sua prática. ${ }^{50}$

Este estudo analítico, diversas vezes mencionado como expressando a visão do grupo de trabalho, ou da Comissão de Direito Internacional, não deve ser confundido com o primeiro. Ainda neste documento, embora sob a responsabilidade do autor Martti Koskenniemi, resta claro em alguns trechos que houve certa "concessão" a perspectivas diversas da "fragmentadora", sendo perceptível a intenção de expressar a existência de visões diversas acerca do fenômeno, embora a visão "positiva” tenha tido menos espaço.

239. 2912th meeting, 9 de agosto.

47 A/CN.4/L.682. United Nations, International Law Commission, General Assembly. 13 April 2006. Fiftyeighth session, Geneva, 1 May-9 June and 3 July-11 August 2006. "Fragmentation of International Law: Difficulties arising from the diversification and expansion of International Law. Report of the Study Group of the International Law Commission Finalized by Martti Koskenniemi. Disponível em: <http://daccessdds-ny.un.org/doc/UNDOC/LTD/G06/610/77/PDF/G0661077.pdf?OpenElement>.

48 UNITED NATIONS. International Law Commission. Report on the work of its fifty-eighth session (1 May to 9 June and 3 July to 11 August 2006). General Assembly Official Records, Sixty-first Session Supplement No. 10 (A/61/10). Disponível em: <http://untreaty.un.org/ilc//reports/2006/english/chp12.pdf>. Parágrafo $235,237$.

49 A/CN.4/L.682. United Nations, International Law Commission, General Assembly. 13 April 2006. Fiftyeighth session, Geneva, 1 May-9 June and 3 July-11 August 2006. "Fragmentation of International Law: Difficulties arising from the diversification and expansion of International Law. Report of the Study Group of the International Law Commission Finalized by Martti Koskenniemi. Disponível em: $<$ http://daccessdds-ny.un.org/doc/UNDOC/LTD/G06/610/77/PDF/G0661077.pdf?OpenElement>. Nota de rodapé * “* The Chairman gratefully acknowledges the help of a number of colleagues who have commented on the topic and provided advice and assistance on particular questions. Special mention should, among them, be made of Professor Campbell McLachlan, Dr. Anders Fischer-Lescano, Professor Gunther Teubner, Professor Emmanuelle Jouannet, Professor Pierre Marie Dupuy and Ms. Isabelle Van Damme. Several NYU interns provided assistance during the Study Group meetings and collecting background materials on particular items. They include Gita Kothari, Cade Mosley, Peter Prows, and Olivia Maloney. Anna Huilaja, Ilona Nieminen and Varro Vooglaid at the Erik Castrén Institute of International Law and Human Rights in Helsinki provided much appreciated help in research. Last but not least, the assistance throughout the years of Ms. Anja Lindroos from the University of Helsinki needs to be recognized. Without her careful notes of the Study Group meetings and her background research this Report would never have materialized. Nevertheless, the contents of this report - including any opinions therein - remain the sole responsibility of its author."

50 UNITED NATIONS. International Law Commission. Report on the work of its fifty-eighth session (1 May to 9 June and 3 July to 11 August 2006). General Assembly Official Records, Sixty-first Session Supplement No. 10 (A/61/10). Disponível em: <http://untreaty.un.org/ilc//reports/2006/english/chp12.pdf>. Parágrafo 239. 2911th meeting, 10 de agosto. 
O que se objetiva evidenciar, a partir da análise do histórico das discussões, e da breve análise do conteúdo de ambos os documentos, é o fato de que existem visões contrastantes acerca da "fragmentação"51 e das respectivas concepções do fenômeno jurídico internacional no bojo do Grupo de Estudos, da CDI e da doutrina internacionalista.

Assim, quando das oportunidades de diálogo intersubjetivo sobre a questão, houve um abrandamento de certas visões extremistas, alarmistas e negativas da temática, como as expressadas no tom do estudo inicial ("individual"), que resultou na modificação do título do tópico, e que se fez presente nas tensões apresentadas nos relatórios anuais sobre os diferentes temas ligados ao tópico.

Contudo, a julgar pelas repetições simplistas do discurso da fragmentação que se alastraram na doutrina sem reflexões mais profundas, reina a impressão de que a visão "positiva" do fenômeno de desenvolvimento e expansão temático-subjetiva do Direito Internacional, em sua natural heterogeneidade, a que se denominou inadequadamente de "fragmentação", restou sub-representada nos documentos finais do grupo de Estudos. Esta impressão é reforçada inclusive pela proposta de um dos membros de que fosse feita uma distinção clara entre aspectos positivos e negativos do fenômeno. ${ }^{52}$

Assim, conforme se passa a verificar, o estudo analítico "finalizado" pelo chairman, Martti Koskenniemi, segue um tom majoritariamente fragmentário, mas reconhece em certos momentos o caráter ambíguo da temática. Na parte introdutória, além de reforçar a existência de visões negativas e positivas sobre o tema, o autor explicita a relatividade do conceito por si só:

(...) In an important sense, "fragmentation" and "coherence" are not aspects of the world but lie in the eye of the beholder. What is new and unfamiliar, will (by definition) challenge

$\overline{51}$ UNITED NATIONS. International Law Commission. Report on the work of its fifty-eighth session (1 May to 9 June and 3 July to 11 August 2006). General Assembly Official Records, Sixty-first Session Supplement No. 10 (A/61/10). Disponível em: <http://untreaty.un.org/ilc//reports/2006/english/chp12.pdf>. Parágrafo 246. Like the majority of academic commentators, the Commission has understood the subject to have both positive and negative sides, as attested to by its reformulation of the title of the topic: "Fragmentation of international law: difficulties arising from the diversification and expansion of international law". On the one hand, fragmentation does create the danger of conflicting and incompatible rules, principles, rule-systems and institutional practices. On the other hand, it reflects the expansion of international legal activity into new fields and the attendant diversification of its objects and techniques. Fragmentation and diversification account for the development and expansion of international law in response to the demands of a pluralistic world. At the same time, it may occasionally create conflicts between rules and regimes in a way that might undermine their effective implementation. Although fragmentation may create problems, they are neither altogether new nor of such nature that they could not be dealt with through techniques international lawyers have used to deal with the normative conflicts that may have arisen in the past.

52 UNITED NATIONS. International Law Commission. Report on the work of its fifty-eighth session (1 May to 9 June and 3 July to 11 August 2006). General Assembly Official Records, Sixty-first Session Supplement No. 10 (A/61/10). Disponível em: <http://untreaty.un.org/ilc//reports/2006/english/chp12.pdf>. Parágrafo 239. 
accustomed ways of thinking and organizing the world. Novelty presents itself as "fragmentation" of the old world. In such case, it is the task of reasoning to make the unfamiliar familiar by integrating it into received patterns of thought or by amending those patterns so that the new phenomenon can be accommodated. Of course, there will always remain some "cognitive dissonance" between the familiar conceptual system and the new information we receive from the world..$^{53}$

Há menção à concepção do Direito Internacional como um sistema, embora de certo modo o discurso escolhido pareça buscar "esvaziar" o significado desse conceito:

It is often said that law is a "system". By this, no more need be meant than that the various decisions, rules and principles of which the law consists do not appear not randomly related to each other. Although there may be disagreement among lawyers about just how the systemic relationship between the various decisions, rules and principles should be conceived, there is seldom disagreement that it is one of the tasks of legal reasoning to establish it.

This cannot be understood as reaffirming something that already "exists" before the systemic effort itself. There is no single legislative will behind international law. Treaties and custom come about as a result of conflicting motives and objectives - they are "bargains" and "package-deals" and often result from spontaneous reactions to events in the environment. $(\ldots)^{54}$

Em mais um trecho, que se segue ao supracitado, fica clara a ambiguidade do texto, e a tensão entre diferentes concepções da ordem jurídica internacional:

(...) But if legal reasoning is understood as a purposive activity, then it follows that it should be seen not merely as a mechanic application of apparently random rules, decisions or behavioural patterns but as the operation of a whole that is directed toward some human objective.

53 A/CN.4/L.682. United Nations, International Law Commission, General Assembly. 13 April 2006. Fiftyeighth session, Geneva, 1 May-9 June and 3 July-11 August 2006. "Fragmentation of International Law: Difficulties arising from the diversification and expansion of International Law. Report of the Study Group of the International Law Commission Finalized by Martti Koskenniemi. Disponível em: $<$ http://daccessdds-ny.un.org/doc/UNDOC/LTD/G06/610/77/PDF/G0661077.pdf?OpenElement>. Parágrafo 20.

54 A/CN.4/L.682. United Nations, International Law Commission, General Assembly. 13 April 2006. Fiftyeighth session, Geneva, 1 May-9 June and 3 July-11 August 2006. "Fragmentation of International Law: Difficulties arising from the diversification and expansion of International Law. Report of the Study Group of the International Law Commission Finalized by Martti Koskenniemi. Disponível em: <http://daccessdds-ny.un.org/doc/UNDOC/LTD/G06/610/77/PDF/G0661077.pdf?OpenElement>. Parágrafo 33-34. 
Legal interpretation, and thus legal reasoning, builds systemic relationships between rules and principles by envisaging them as parts of some human effort or purpose. Far from being merely an "academic" aspect of the legal craft, systemic thinking penetrates all legal reasoning, including the practice of law-application by judges and administrators. 32 This results precisely from the "clustered" nature in which legal rules and principles appear. But it may also be rationalized in terms of a political obligation on law-appliers to make their decisions cohere with the preferences and expectations of the community whose law they administer. ${ }^{55}$

A definição de critérios para a solução de antinomias na ordem jurídica internacional é a tarefa objetiva de todo este estudo. Desse modo, após esta introdução das divergências sobre a fragmentação, o Estudo analítico adentra no objetivo das conclusões apresentas pelo grupo de Estudos: a sistematização de critérios para a solução de conflitos de normas no Direito Internacional.

A solução desses conflitos se dá (a) pela tentativa de harmonizar os dispositivos aparentemente em conflito por meio da atividade interpretativa em perspectiva sistêmica; ou (b) pelo reconhecimento de relações de prioridade na aplicação de normas, por meio dos critérios de (i) especialidade; (ii) posterioridade e (iii) superioridade. É por intermédio da aplicação desses instrumentos que o Direito Internacional se molda e se concretiza como um sistema teleologicamente direcionado. ${ }^{56}$

Assim, a escolha de aplicação de normas ao caso concreto pode se dar de modo a resguardar interesses e valores. ${ }^{57}$ Embora não se posicione em relação à teoria da constitucionalização do Direito Internacional, o estudo explicita o reconhecimento no

55 A/CN.4/L.682. United Nations, International Law Commission, General Assembly. 13 April 2006. Fiftyeighth session, Geneva, 1 May-9 June and 3 July-11 August 2006. "Fragmentation of International Law: Difficulties arising from the diversification and expansion of International Law. Report of the Study Group of the International Law Commission Finalized by Martti Koskenniemi. Disponível em: $<$ http://daccessdds-ny.un.org/doc/UNDOC/LTD/G06/610/77/PDF/G0661077.pdf?OpenElement>. Parágrafo 34-35.

56 A/CN.4/L.682. United Nations, International Law Commission, General Assembly. 13 April 2006. Fiftyeighth session, Geneva, 1 May-9 June and 3 July-11 August 2006. "Fragmentation of International Law: Difficulties arising from the diversification and expansion of International Law. Report of the Study Group of the International Law Commission Finalized by Martti Koskenniemi. Disponível em: $<$ http://daccessdds-ny.un.org/doc/UNDOC/LTD/G06/610/77/PDF/G0661077.pdf?OpenElement>. Parágrafo 36. (...)

Through it, the legal profession articulates, and gives shape and direction to law. Instead of a random collection of directives, the law begins to assume the shape of a purposive (legal) system."

57 A/CN.4/L.682. United Nations, International Law Commission, General Assembly. 13 April 2006. Fiftyeighth session, Geneva, 1 May-9 June and 3 July-11 August 2006. "Fragmentation of International Law: Difficulties arising from the diversification and expansion of International Law. Report of the Study Group of the International Law Commission Finalized by Martti Koskenniemi. Disponível em: $<$ http://daccessdds-ny.un.org/doc/UNDOC/LTD/G06/610/77/PDF/G0661077.pdf?OpenElement>. Parágrafo 325. 
caso Corfu Chanel (1949) de "elementary considerations of humanity" que limitam a soberania estatal, e no caso legalidade do Uso de Armas Nucleares (1996) da existência de "intransgressible principles of international customary law". ${ }^{58}$

Em sua parte conclusiva, o estudo chama atenção para a coerência do Direito Internacional, virtude formal e abstrata, que garante segurança e previsibilidade ao ordenamento jurídico. É possível, contudo, reconhecer juntamente com a coerência, o pluralismo como valor constitutivo do sistema..$^{59} \mathrm{~A}$ fragmentação promoveria, assim, uma passagem do Direito Internacional em direção ao pluralismo jurídico, de modo a referir constantemente aos recursos do Direito Internacional geral, especialmente as regras da CVDT, direito costumeiro e princípios gerais do Direito Internacional. ${ }^{60}$

Assim como constava de um dos relatórios preliminares, e em afirmação surpreendentemente pouco divulgada pelos defensores da perspectiva fragmentária, uma das principais conclusões é que a emergência de regimes especializados (que não

58 A/CN.4/L.682. United Nations, International Law Commission, General Assembly. 13 April 2006. Fiftyeighth session, Geneva, 1 May-9 June and 3 July-11 August 2006. "Fragmentation of International Law: Difficulties arising from the diversification and expansion of International Law. Report of the Study Group of the International Law Commission Finalized by Martti Koskenniemi. Disponível em: <http://daccessdds-ny.un.org/doc/UNDOC/LTD/G06/610/77/PDF/G0661077.pdf?OpenElement>. Parágrafo 326. 326. There has never been any doubt about the fact that some considerations in the international world are more important than others, and must be legally recognized as such - although how that sense of importance could be articulated has been the subject of lasting academic controversy. Here it is not suggested to take a position on that controversy - for example, on the role of natural law or political justice in international law or on whether or to what extent international law might be in a process of "constitutionalization". Irrespective of the difficulty of finding a general vocabulary that would express the role of the sense of importance of particular norms, the practice of international law has always recognized the presence of some norms that are superior to other norms and must therefore be given effect. (...)

59 A/CN.4/L.682. United Nations, International Law Commission, General Assembly. 13 April 2006. Fiftyeighth session, Geneva, 1 May-9 June and 3 July-11 August 2006. "Fragmentation of International Law: Difficulties arising from the diversification and expansion of International Law. Report of the Study Group of the International Law Commission Finalized by Martti Koskenniemi. Disponível em: $<\mathrm{http} / / /$ daccess-dds-ny.un.org/doc/UNDOC/LTD/G06/610/77/PDF/G0661077.pdf?OpenElement>. Parágrafo 491. "Fragmentation puts to question the coherence of international law. Coherence is valued positively owing to the connection it has with predictability and legal security. Moreover, only a coherent legal system treats legal subjects equally. Coherence is, however, a formal and abstract virtue. For a legal system that is regarded in some respects as unjust or unworkable, no added value is brought by the fact of its being coherently so. Therefore, alongside coherence, pluralism should be understood as a constitutive value of the system. Indeed, in a world of plural sovereignties, this has always been so".

${ }_{60}$ A/CN.4/L.682. United Nations, International Law Commission, General Assembly. 13 April 2006. Fiftyeighth session, Geneva, 1 May-9 June and 3 July-11 August 2006. "Fragmentation of International Law: Difficulties arising from the diversification and expansion of International Law. Report of the Study Group of the International Law Commission Finalized by Martti Koskenniemi. Disponível em: $<$ http://daccessdds-ny.un.org/doc/UNDOC/LTD/G06/610/77/PDF/G0661077.pdf?OpenElement>. Parágrafo 492. "Even as international law's diversification may threaten its coherence, it does this by increasing its responsiveness to the regulatory context. Fragmentation moves international law in the direction of legal pluralism but does this, as the present report has sought to emphasize, by constantly using the resources of general international law, especially the rules of the VCLT, customary law and "general principles of law recognized by civilized nations. (...)". 
devem ser chamados de regimes autocontidos) não compromete a segurança jurídica, previsibilidade ou igualdade dos sujeitos do Direito Internacional. ${ }^{61}$

Neste contexto, as técnicas lex specialis e lex posterior, e a relação de acordos inter se, jus gogens e erga omnes, conforme disposto no Relatório de conclusões do grupo de estudos, são recursos básicos para lidar com os problemas oriundos da fragmentação, e podem ser usados de modo a concretizar preocupações legítimas da sociedade internacional, tais como desenvolvimento econômico, proteção dos direitos humanos, segurança, e proteção ambiental.

Por fim, como segunda conclusão principal do estudo tem-se a afirmação de que um sistema homogêneo e hierárquico não é realisticamente disponível para acabar com os conflitos de normas, motivo pelo qual o Direito Internacional terá que operar dentro de uma área onde as exigências de pluralismo razoável e coerência apontarão em direções diferentes.

O relatório oficial do grupo de estudos, por sua vez, enumera diversas conclusões, que acabam por reforçar o caráter unitário, sistêmico e coerente da ordem jurídica internacional. A primeira conclusão que se apresenta é nesse sentido:

(1) International law as a legal system. International law is a legal system. Its rules and principles (i.e. its norms) act in relation to and should be interpreted against the background of other rules and principles. As a legal system, international law is not a random collection of such norms. There are meaningful relationships between them. Norms may thus exist at higher and lower hierarchical levels, their formulation may involve greater or lesser generality and specificity and their validity may date back to earlier or later moments in time.

O Relatório explicita a existência do princípio da harmonização, que guarda próxima relação com a percepção do Direito Internacional enquanto um sistema integrado de direitos e obrigações:

(4) The principle of harmonization. It is a generally accepted principle that when several norms bear on a single issue they should, to the extent possible, be interpreted so as to give rise to a single set of compatible obligations.

61 A/CN.4/L.682. United Nations, International Law Commission, General Assembly. 13 April 2006. Fiftyeighth session, Geneva, 1 May-9 June and 3 July-11 August 2006. "Fragmentation of International Law: Difficulties arising from the diversification and expansion of International Law. Report of the Study Group of the International Law Commission Finalized by Martti Koskenniemi. Disponível em: $<$ http://daccessdds-ny.un.org/doc/UNDOC/LTD/G06/610/77/PDF/G0661077.pdf?OpenElement>. Parágrafo 492. 
Como consequência natural deste raciocínio, conclusões seguintes destacam que a técnica lex specialis, que concede precedência na aplicação de regras ou conjunto de normas mais específicas, não apaga a relevância da lei geral, que se manifesta fortemente no preenchimento de brechas normativas e na falência do conjunto de normas:

(9) The effect of lex specialis on general law. The application of the special law does not normally extinguish the relevant general law. That general law will remain valid and applicable and will, in accordance with the principle of harmonization under conclusion (4) above, continue to give direction for the interpretation and application of the relevant special law and will become fully applicable in situations not provided for by the latter.

(...)

(15) The role of general law in special regimes: Gapfilling. The scope of special laws is by definition narrower than that of general laws. It will thus frequently be the case that a matter not regulated by special law will arise in the institutions charged to administer it. In such cases, the relevant general law will apply.

(16) The role of general law in special regimes: Failure of special regimes. Special regimes or the institutions set up by them may fail. Failure might be inferred when the special laws have no reasonable prospect of appropriately addressing the objectives for which they were enacted.

As conclusões também reafirmam a relevância do aqui denominado "objetivo da integração sistêmica", elevado ao status de princípio por alguns doutrinadores, que confere à atividade de interpretação de um tratado o significado de integração destas normas em face das demais existentes no sistema jurídico internacional. Assim, lê-se:

(17) Systemic integration. Article 31 (3) (c) VCLT provides one means within the framework of the VCLT, through which relationships of interpretation (referred to in conclusion (2) above) may be applied. It requires the interpreter of a treaty to take into account "any relevant rules of international law applicable in relations between the parties". The article gives expression to the objective of "systemic integration" according to which, whatever their subject matter, treaties are a creation of the international legal system and their operation is predicated upon that fact.

(18) Interpretation as integration in the system. Systemic integration governs all treaty interpretation, the other relevant aspects of which are set out in the other paragraphs of articles 31-32 VCLT. These paragraphs describe a process of legal reasoning, in which particular elements will 
have greater or less relevance depending upon the nature of the treaty provisions in the context of interpretation. In many cases, the issue of interpretation will be capable of resolution with the framework of the treaty itself. Article 31 (3) (c) deals with the case where material sources external to the treaty are relevant in its interpretation. These may include other treaties, customary rules or general principles of law.

Como não poderia faltar, as conclusões do grupo continuam com o reconhecimento da hierarquia no Direito Internacional como um critério que erige valores elementares da sociedade internacional em normas inderrogáveis, e concluem com a afirmação de que inclusive o critério hierárquico deve ser conjugado com o princípio da harmonização:

(31) Hierarchical relations between norms of international law. The main sources of international law (treaties, custom, general principles of law as laid out in Article 38 of the Statute of the International Court of Justice) are not in a hierarchical relationship inter se. Drawing analogies from the hierarchical nature of domestic legal system is not generally appropriate owing to the differences between the two systems. Nevertheless, some rules of international law are more important than other rules and for this reason enjoy a superior position or special status in the international legal system. This is sometimes expressed by the designation of some norms as "fundamental" or as expressive of "elementary considerations of humanity" 62 or "intransgressible principles of international law". ${ }^{63}$ What effect such designations may have is usually determined by the relevant context or instrument in which that designation appears.(...)

(42) Hierarchy and the principle of harmonization. Conflicts between rules of international law should be resolved in accordance with the principle of harmonization, as laid out in conclusion (4) above. In the case of conflict between one of the hierarchically superior norms referred to in this section and another norm of international law, the latter should, to the extent possible, be interpreted in a manner consistent with the former. In case this is not possible, the superior norm will prevail.

62 Corfu Channel case (United Kingdom v. Albania) I.C.J. Reports 1949, p. 22.

63 Legality of the Threat or Use of Nuclear Weapons case, Advisory Opinion, I.C.J. Reports 1996, Parágrafo 79. 
Resta claro, novamente, que o grupo de estudos da Comissão de Direito Internacional conclui suas investigações com uma perspectiva conciliadora, que vislumbra harmonia e sistematização no Direito Internacional, embora parta de vocabulários e pressupostos ligados a uma visão fragmentária da ordem jurídica internacional. De todo modo, e principalmente em razão da proliferação na doutrina de uma suposta endemia fragmentadora no Direito Internacional, cumpre explicitar a contracorrente da perspectiva sistêmica do Direito Internacional, na busca por outra interpretação da evolução da normatividade internacional.

\section{O Direito Internacional e o discurso da fragmentação: uma visão crítica}

Em uma visão crítica do discurso da fragmentação, afirma-se que se um processo de transformação e especialização do Direito Internacional é visível, isto é, sua normatividade tem abarcado fatos cada vez mais amplos e complexos, que exigem, portanto, a formação de ramos especializados, esses não constituem regimes limitados, mas subsistemas que coexistem dentro do mesmo sistema jurídico internacional.

Deve-se, pois, manter a cautela ao identificar o fenômeno de expansão e desenvolvimento evolutivo do Direito Internacional como fragmentação, já que esse vocábulo pode implicitamente trazer um sentido negativo à expansão do Direito Internacional, ao conectá-lo à ideia de quebra e redução a fragmentos, e assim afastálo da noção de unidade que permeia todo o sistema internacional, e é essencial à sua caracterização como tal. Por outro lado, embora esta visão negativa não seja a única possível sobre o fenômeno, e não tenha sido efetivamente chancelada pela Comissão de Direito Internacional, foi esta a perspectiva que logrou maior destaque no estudo analítico "finalizado" por Martti Koskenniemi.

Cumpre destacar que esta heterogeneidade que se confere à fragmentação é característica própria da ordem jurídica internacional, que tem nesta heterogeneidade sua noção de desenvolvimento evolutivo. Assim, as facetas apontadas como ligadas à suposta fragmentação do Direito Internacional são, em verdade, uma reafirmação de sua juridicidade plural e única.

Nas palavras de Wagner Menezes, o sistema jurídico internacional possui inerente um "pluralismo endógeno":

A sociedade internacional se caracteriza pela ampla interrelação dos vários atores internacionais, que se traduz na intensificação das interações transnacionais, supranacionais, ou cosmopolitas, mediante práticas interestatais, de caráter público ou privado, nas práticas capitalistas globais, ou interações sociais e culturais entre os povos. E é bastante diferente daquela sociedade westfaliana, onde foi gerado o Direito Internacional Clássico, que orienta até nossos dias 
a aplicação de normas e a regulamentação das relações internacionais e, expressam um pluralismo endógeno que deságua na necessidade do estabelecimento de um conjunto de regras e de mecanismos para pacificar as relações globais, sejam de Estados, dos povos ou particulares. É então que a sociedade dos povos tem como garantia o direito internacional e a sistematização a partir dele de Cortes Internacionais para solucionar seus conflitos, a partir de princípios legitimados no plano internacional. ${ }^{64}$

Nesta concepção, o discurso da fragmentação parte de premissas equívocas, e utiliza-se de conceitos alheios à formulação conceitual do Direito Internacional. ${ }^{65}$ Ademais, o tom alarmista que se buscou imprimir ao discurso de esfacelamento do Direito Internacional, a partir da proliferação de "regimes" especializados e seus respectivos tribunais, não se sustenta em face de uma análise teórica mais detida e diante da prática da realidade internacional. ${ }^{66}$

A este respeito, a multiplicação de Tribunais Internacionais observada nas últimas décadas, como resultado dessa evolução da normatividade no seio da sociedade internacional e do "império do direito" sob as relações internacionais, é fenômeno positivo de concretização da justiça e dos objetivos do Direito Internacional. Como se verá adiante neste trabalho, é na atividade de adjudicação que o juiz concretiza o comando abstrato da norma, completando o sistema por meio da colmatação de lacunas normativas, e conferindo-lhe efetividade.

Assim, nos filiamos aos juristas que afirmam ocorrer, diante da expansão e especialização do Direito Internacional, acompanhada da jurisdicionalização, ${ }^{67}$ uma verdadeira amplificação e reafirmação da normatividade internacional e de sua

64 MENEZES, Wagner. A jurisdicionalização do direito internacional: conflitos de competência entre Tribunais Internacionais, sua prevenção e resolução. Tese (Livre Docência), Faculdade de Direito, Universidade de São Paulo, São Paulo, 2011. p. 103.

65 Wagner Menezes chama a atenção para o caráter não jurídico das análises desqualificadoras e fragmentadoras do Direito Internacional, baseadas em fundamentos teóricos equivocados. MENEZES, Wagner. $A$ jurisdicionalização do direito internacional: conflitos de competência entre Tribunais Internacionais, sua prevenção e resolução. Tese (Livre Docência), Faculdade de Direito, Universidade de São Paulo, São Paulo, 2011. p. 173. Um exemplo claro disso é o conceito de "regimes", advindo das Relações Internacionais, e que se mostra equivocado no desenrolar dos estudos sobre a temática, ao implicitamente trazer um isolamento face ao sistema jurídico internacional "geral", que não ocorre na realidade.

66 Embora datado de 1998, o estudo empírico realizado pelo autor conclui que as situações nas quais a interpretação por Tribunais Internacionais das normas internacionais se dá de forma contraditória é excepcional. CHARNEY, Jonathan. Is International Law threatened by multiple international tribunals? Recueil des Cours: Collected Courses of the Hague Academy of International Law, London/Boston, v. 271, p. 247-250, 1998.

${ }_{67}$ ROMANO, Cesare. Can you hear me now? The case for extending judicial network. Chicago Journal of International Law, Chicago, v. 10, n. 1, p. 233-273, 2009. 
institucionalização. ${ }^{68}$ Se essa especialização promove um pluralismo dentro do Direito Internacional, trata-se de um pluralismo composto de subsistemas que coexistem, e que não desabona a unidade e a coerência desse Direito como sistema jurídico. Reafirmamos, portanto, a unidade do Direito Internacional, que passa por uma reafirmação, em todos os diferentes ramos especializados, dos fundamentos e valores essenciais da disciplina, concomitante a uma valorização do homem como sujeito e fim último do Direito Internacional. ${ }^{69}$

Admite-se, por um lado, que o estudo do tema por um órgão como a Comissão de Direito Internacional da ONU teve o mérito de suscitar o debate e a reflexão na academia sobre os objetivos, os fundamentos e a evolução do Direito Internacional. O que se critica, novamente, é a aceitação deste vocabulário e de suas suposições - que inclusive acabam por ser contraditas pelas conclusões do relatório final - por grande parte da doutrina, sem que sejam devidamente analisados e avaliados.

\section{Considerações finais: a perspectiva sistêmica do Direito Internacional}

Tendo-se buscado analisar criticamente o mito da Fragmentação do Direito Internacional, a partir da decodificação de sua linguagem e do desfazimento de sua compreensão como uma análise jurídica, cumpre-nos, à guisa de conclusão, relembrar a existência de perspectiva doutrinária que procura enfatizar a visão sistêmica do Direito Internacional.

Em estudos sobre a história semântica do termo sistema, Mário G. Losano explicita que no grego clássico o termo tinha seus diversos significados conectados à ideia de agregação, e por isso usado em referência à ordem do mundo, seja ela ligada à sociedade ou ao cosmos. ${ }^{70}$ Esse termo abstrato foi posteriormente recepcionado com dificuldades pelo latim, língua inclinada ao concreto, que tendeu a substituir o termo dos textos gregos por metáforas originadas da arquitetura e explicitadas pelos termos construere e structura. É essa a explicação, segundo o autor, para o entrelaçamento do significado semântico dos termos sistema e estrutura, que embora com particularidades, tem a função de designar uma natural tendência do jurista, que concebe sua disciplina como uma totalidade sistemática, ligada à ordem e harmonia. ${ }^{71}$

\footnotetext{
68 MENEZES, Wagner. Ordem global e transnormatividade. Ijuí: Ed. Unijuí, 2005.

69 TRINDADE, Antônio Augusto Cançado. Os rumos do direito internacional contemporâneo: de um jus inter gentes a um novo jus gentium no século XXI. In: TRINDADE, Antônio Augusto Cançado. $O$ direito internacional em um mundo em transformação. Rio de Janeiro: Renovar, 2002. p. 1.039-1.109.

70 LOSANO, Mario G. Sistema e estrutura no direito: das origens à escola histórica. São Paulo: Editora WMF Martins Fontes, 2008. v. 1. p. 3.

71 Assim explicita: “(...) esses termos não são usados simultaneamente em todas as línguas, mas tiveram diversos êxitos: são as facetas historicamente condicionadas de um componente constante do pensamento
} 
A presença de tal notável tentativa de sistematização passou evolutivamente de uma preocupação intuitiva a um desenvolvimento teórico e técnico desencadeado pelo pensamento de filósofos e, posteriormente, de juristas.

Em seu curso geral da Academia de Direito Internacional de Haia, Georges Abi-Saab esclarece que a conceituação dos sistemas e dos ordenamentos jurídicos, a prescindir do foco na norma em si, é reação face às teorias de Jonh Austin e da escola alemã, resultantes do endeusamento do Estado, e que priorizaram a sanção como definição do Direito, tendo como consequência a negação radical da existência do Direito Internacional como Direito. Para Austin, o Direito Internacional se tratava de uma 'moralidade positiva', enquanto a escola alemã o interpretava como um braço ou ramo do direito interno, à semelhança do Direito Internacional Privado. Assim, as teorias (i) da escola normativista (Kelsen); (ii) da escola institucionalista (Renaud, Romano); e (iii) da escola de Oxford (Hart), seriam reações àquele entendimento, e tentativas de analisar as facetas da noção de ordenamento e sistema jurídico. ${ }^{72}$

A teoria pura do direito de Hans Kelsen se propunha a eliminar do direito os elementos não jurídicos e a abstrair a estrutura das normas de seu conteúdo substancial, para estudá-las como partes articuladas do ordenamento jurídico. Segundo Kelsen, a validade da norma se relaciona ao pertencimento e coerência da norma com o ordenamento jurídico. $\mathrm{O}$ autor traçou uma estrutura piramidal para retratar o ordenamento jurídico, na qual as normas inferiores buscam sua condição de validade e existência nas normas superiores, o que culmina na norma fundamental..$^{73}$ A grundnorm seria, pois, a base ideológica de legitimidade e aceitação social do ordenamento jurídico, mas em sendo uma norma hipotética, se coloca como um recurso lógico para conferir completude e fechamento ao sistema jurídico analisado em abstrato. ${ }^{74}$

No entendimento de Santi Romano, por sua vez, a essência do Direito não estaria na norma, mas em suas instituições, pois a primeira seria incapaz de explicar a unidade e identidade própria do sistema em si, e as últimas seriam capazes de dar efeito às primeiras. Somente as instituições confeririam ao sistema jurídico a objetividade e

humano, principalmente ocidental, em geral, e do pensamento jurídico em particular." LOSANO, Mario G. Sistema e estrutura no direito: das origens à escola histórica. São Paulo: Editora WMF Martins Fontes, 2008. v. 1, p. 5.

72 ABI-SAAB, Georges. Cours général de droit international public. Recueil des Cours: Collected Courses of the Hague Academy of International Law, London/Boston, v. 207, p. 9-464, 1987.

73 KELSEN, Hans. Teoria pura do direito. 7. ed. São Paulo: Editora WMF Martins Fontes, 2006. passim.

74 Embora haja ampla controvérsia a respeito no conteúdo da grundnorm, em sua obra "Princípios do Direito Internacional" o autor explicita que o sustentáculo da pirâmide de cada ordenamento jurídico nacional encontra-se no reconhecimento que o Direito Internacional confere também ao Estado. Assim, pode-se interpretar que acima dos ordenamentos jurídicos nacionais encontra-se o Direito Internacional, sendo uma das possibilidades teóricas para a análise da norma fundamental. 
a sanção, características distintivas do Direito, segundo o autor, e das quais a norma individualmente seria esvaziada.

O Direito e as instituições seriam, pois, manifestações ou expressões da realidade e da unidade de um corpo social; e a ordem social e a jurídica seriam dimensões da mesma sociedade. ${ }^{75}$ Embora reconheça o valor de sua perspectiva holística, focada na relação entre sociedade e sistema jurídico, Georges Abi-Saab critica a minimização excessiva do papel da norma no ordenamento jurídico na perspectiva de Romano, vez que seriam elas garantidoras da própria coerência e integração lógica do sistema, bem como do arcabouço institucional. ${ }^{76}$

A teoria de Hart, por sua vez, oferece uma terceira concepção de sistema jurídico: um conjunto composto por regras primárias e regras secundárias. As regras primárias prescrevem comportamentos, as regras secundárias regem a estrutura, função e modalidades das regras primárias e de organização do próprio sistema. As regras secundárias se dividem em (a) regras de reconhecimento, pelas quais o sistema jurídico reconhece aquelas regras que lhe pertencem; (b) regras de mudança, que tratam do nascimento, modificação e desaparecimento das regras; e (c) regras de adjudicação, que tratam da aplicação de regras gerais a situações concretas e das sanções. ${ }^{77}$

Por fim, a perspectiva de Norberto Bobbio sobre o ordenamento jurídico, que em muito influencia a ciência jurídica contemporânea, se apresenta como tentativa de releitura da teoria de Kelsen, inegavelmente influenciada pelo pensamento de Romano, e projetada para além da concepção de Hart. Dessa maneira, se inicialmente Bobbio dá um passo atrás ao conceituar o ordenamento jurídico simplesmente como "um conjunto de normas", ${ }^{78}$ que pressuporia como única condição a existência de mais de uma norma, o autor vai além ao analisar os elementos que conectam essas normas participantes do sistema entre si. Terá espaço, portanto, em sua visão, as facetas da (a) unidade; (b) coerência e (c) completude do sistema.

Assim, um ordenamento normativo se apresenta como unitário quando deriva de fontes, que por sua vez emanam do mesmo núcleo justificador dessas normas, a norma fundamental à qual todas as fontes podem ser remontadas. Sendo somente unitário, o ordenamento jurídico não se caracterizaria propriamente como sistema, pois esse pressupõe adicionalmente a coerência, para que resulte em uma "unidade sistemática". ${ }^{9}$

75 ROMANO, Santi. O ordenamento jurídico. Florianópolis: Boiteux, 2008. Passim.

76 ABI-SAAB, Georges. Cours général de droit international public. Recueil des Cours: Collected Courses of the Hague Academy of International Law, London/Boston, v. 207, p. 9-464, 1987.

77 HART, H. L. A. O conceito de direito. São Paulo: Editora WMF Martins Fontes, 2009. Passim.

78 BOBBIO, Norberto. Teoria do ordenamento jurídico. 6. ed. Brasília: Editora Universidade de Brasília, 1995. p. 31.

79 E assim explana o autor: "Entendemos por sistema uma totalidade ordenada, um conjunto de entes entre 
O autor toma, pois, o sentido de sistema como um todo no qual não podem existir normas incompatíveis. A coerência deriva não da inexistência fática de conflito entre as normas, mas da eleição de critérios para a solução dessas antinomias, de modo a manter a justiça do sistema. ${ }^{80}$ Por fim, remetendo-nos à noção de completude, Bobbio a explicita como característica do sistema jurídico pela qual o juiz pode nele encontrar norma para solucionar qualquer caso.

Transpondo esse conceito de sistema ao Direito Internacional, reafirmamos a existência de um sistema jurídico internacional, que tem a sua unidade, coerência garantida pela aplicação de critérios de solução de incongruências, nos quais assume especial relevância os princípios, enquanto vetores axiológicos e integradores, fios condutores, linhas mestras dos valores fundantes da sociedade internacional. É certo que a completude do sistema jurídico internacional, por sua vez, se concretiza por meio da atividade de interpretação pelo juiz, que se torna responsável por integrar os diferentes preceitos normativos apreendidos pelas fontes do Direito Internacional, e diante de um caso concreto, oferecer a solução que esteja em harmonia com este sistema.

Assim, a evolução das relações na sociedade internacional e, portanto, do Direito Internacional que surge de tal sociedade e que se destina a ela, não evidencia um enfraquecimento em suas bases ou características sistêmicas. Ao contrário, no paradigma "pós-moderno" do sistema internacional, os fundamentos deste cada vez mais complexo sistema se reconstroem, nas palavras de Paulo Borba Casella, como embasamento para uma "ordenação teleologicamente humana do mundo". ${ }^{81 / 82 / 83}$

os quais existe uma certa ordem. Para que se possa falar de uma ordem, é necessário que os entes que a constituem não estejam somente em relacionamento de coerência entre si. Quando nos perguntamos se um ordenamento constitui um sistema, nos perguntamos se as normas que o compõem estão num relacionamento de coerência entre si, e em que condições é possível essa relação." BOBBIO, Norberto. Teoria do ordenamento jurídico. 6. ed. Brasília: Editora Universidade de Brasília, 1995. p. 71.

80 BOBBIO, Norberto. Teoria do ordenamento jurídico. 6. ed. Brasília: Editora Universidade de Brasília, 1995. p. 113.

81 CASELLA, Paulo Borba. Direito internacional pós-moderno e a revisão dos modelos institucional e normativo. In: CASELLA, Paulo Borba. BRIC - Brasil, Rússia, Índia, China e África do Sul: uma perspectiva de cooperação internacional. São Paulo: Atlas, 2011, p. 113-137. p. 121.

82 Assim postula o autor: "Ante as mutações verificadas na nova realidade, é preciso alcançar nova regulação internacional. De fundamentos mais amplos, para assegurar os resultados adequados dessa construção do direito internacional pós-moderno". CASELLA, Paulo Borba. Direito internacional pós-moderno e a revisão dos modelos institucional e normativo. In: CASELLA, Paulo Borba. BRIC - Brasil, Rússia, Índia, China e África do Sul: uma perspectiva de cooperação internacional. São Paulo: Atlas, 2011, p. 113-137. p. 126.

83 O paradigma contemporâneo da sociedade internacional exige, pois, uma nova formulação do gerenciamento dos conflitos, de modo a integrar os diferentes setores do Estado em respeito ao "international rule of law". Em outro texto, Paulo Borba Casella reforça esta necessidade: "A conclusão se põe no sentido de que os Estados precisam estar sujeitos, no âmbito externo, a sistemas de pesos e contrapesos, ou à institucionalização de sistema normativo que lhes limite o alcance da esfera de discricionariedade. Na medida em que os mecanismos institucionais instaurem "Estado de Direito" no âmbito internacional, pode-se ter evolução 
Por fim, vale lembrar a visão explicitada por Pierre-Marie Dupuy, em seu curso de Haia, destacando que o sentido de fragmentação existente no mundo contemporâneo, a qual não se refere à normatividade internacional, mas às diferenças e divisões da própria humanidade em suas civilizações nos exige exatamente um fortalecimento do Direito Internacional. ${ }^{84}$ É na sua capacidade de normatização para além das diferenças que o sistema jurídico internacional encontra o seu valor e reforça suas características como instrumento universal de regulação positiva da conduta dos seus sujeitos.

Artigo finalizado em Lisboa, 30 de abril de 2015.

\section{Referências}

ABI-SAAB, Georges. Cours général de droit international public. Recueil des Cours: Collected Courses of the Hague Academy of International Law, London/Boston, v. 207, p. 9-464, 1987.

BOBBIO, Norberto. Teoria do ordenamento jurídico. 6. ed. Brasília: Editora Universidade de Brasília, 1995.

CASELLA, Paulo Borba. Direito internacional pós-moderno e a revisão dos modelos institucional e normativo. In: CASELLA, Paulo Borba. BRIC - Brasil, Rússia, Índia, China e África do Sul: uma perspectiva de cooperação internacional. São Paulo: Atlas, 2011, p. 113-137.

CASELLA, Paulo Borba. Fundamentos e perspectivas do direito internacional pós-moderno. Revista da Faculdade de Direito da Universidade de São Paulo, v. 101, p. 433-466, jan./dez. 2006.

CHARNEY, Jonathan. Is international law threatened by multiple international tribunals? Recueil des Cours: Collected Courses of the Hague Academy of International Law, London/Boston, v. 271, p. 247-250, 1998.

COMISSÃO DE DIREITO INTERNACIONAL. Diversos documentos consultados: <http:// untreaty.un.org/ilc/ilcintro.htm>.

DUPUY, Pierre-Marie. L'unité de l'ordre juridique international: cours général de droit international public (2000). Recueil des Cours: Collected Courses of the Hague Academy of International Law, London/Boston, v. 297, p. 9-489, 2002.

HART, H. L. A. O conceito de direito. São Paulo: Editora WMF Martins Fontes, 2009.

semelhante ao alcançado nas ordens internas, mediante a institucionalização das garantias constitucionais internas. [...]" CASELLA, Paulo Borba. Fundamentos e perspectivas do direito internacional pós-moderno. Revista da Faculdade de Direito da Universidade de São Paulo, v. 101, p. 433-466, jan./dez. 2006. p. 441.

84 DUPUY, Pierre-Marie. L'unité de l'ordre juridique international: cours général de droit international public (2000). Recueil des Cours: Collected Courses of the Hague Academy of International Law, London/Boston, v. 297, p. 9-489, 2002. 
KELSEN, Hans. Teoria pura do direito. 7. ed. São Paulo: Editora WMF Martins Fontes, 2006.

LOSANO, Mario G. Sistema e estrutura no direito: das origens à escola histórica. São Paulo: Editora WMF Martins Fontes, 2008. v. 1.

MENEZES, Wagner. A jurisdicionalização do direito internacional: conflitos de competência entre Tribunais Internacionais, sua prevenção e resolução. Tese (Livre Docência) - Faculdade de Direito, Universidade de São Paulo, São Paulo, 2011.

MENEZES, Wagner. Ordem global e transnormatividade. Ijuí: Ed. Unijuí, 2005.

ROMANO, Cesare. Can you hear me now? The case for extending judicial network. Chicago Journal of International Law, Chicago, v. 10, n. 1, p. 233-273, 2009.

ROMANO, Santi. O ordenamento jurídico. Florianópolis: Boiteux, 2008.

TRINDADE, Antônio Augusto Cançado. Os rumos do direito internacional contemporâneo: de um jus inter gentes a um novo jus gentium no século XXI. In: TRINDADE, Antônio Augusto Cançado. O direito internacional em um mundo em transformação. Rio de Janeiro: Renovar, 2002. 